\title{
Aplikasi Penjadwalan Dan Booking Online Menggunakan Teknologi Android Webview
}

\author{
Fietri Setiawati Sulaeman ${ }^{1}$ M. Firaz Fakhriza Nurjaman ${ }^{2}$ \\ Program Studi Teknik Informatika \\ fietrisetiawati@email.com ${ }^{1}$,Firaz104@hotmail.com²
}

\begin{abstract}
Rajawali Futsal is one of the businesses providing futsal fields in the city of Cianjur. Rajawa Futsal is engaged in services, namely providing futsal field rental services, especially for people who like to play futsal. In carrying out daily activities it still uses manual methods, such as scheduling, booking process and making reports by writing them in a book. Online Scheduling and Booking Application in Rajawali Futsal Cianjur uses the Waterfall model paradigm with UML (unified modeling language) with tools used to design namely usecase diagrams, Activity Diagrams, class diagrams and Sequence diagrams. While database application development tools use MySQL with PHP programming language. The system designed has the advantage of making it easier for admins to schedule, the online booking process, as well as for managing members and this system can make it easier in terms of totaling the total payments obtained automatically in making reports both reports daily, monthly or annually.
\end{abstract}

Keywords: Scheduling, Futsal, Booking, PHP

\begin{abstract}
Abstrak
Rajawali Futsal merupakan salah satu usaha penyedia lapangan futsal yang ada di kota Cianjur. Rajawa Futsal bergerak dalam bidang jasa, yaitu memberi pelayanan penyewaan lapangan futsal khususnya untuk masyarakat yang hobi bermain olahraga futsal. Dalam pelaksanaan kegiatan sehari-hari masih menggunakan cara manual, seperti penjadwalan, proses Booking dan pembuatan laporan-laporan dengan cara menuliskannya didalam buku. Aplikasi Penjadwalan dan Booking Online di Rajawali Futsal Cianjur menggunakan paradigma model Waterfall dengan UML (unified modeling language) dengan alat yang digunakan untuk merancang yaitu usecase diagram, Activity Diagram, class diagram dan Sequence diagram. Sedangkan alat pembangunan aplikasi database menggunakan MySQL dengan bahasa pemograman PHP. Sistem yang dirancang mempunyai kelebihan dalam mempermudah admin untuk melakukan penjadwalan, proses Booking online, serta untuk mengelola member dan sistem ini dapat mempermudah dalam hal melakukan penjumlahan total pembayaran yang diperoleh dengan otomatis dalam pembuatan laporan baik laporan perhari, perbulan ataupun pertahun.
\end{abstract}

Kata kunci: Penjadwalan, Futsal, Booking, PHP

\section{Pendahuluan}

Rajawali Futsal merupakan salah satu tempat penyewaan lapangan futsal yang ada di Kabupaten Cianjur, Provinsi Jawa Barat, Indonesia. Sama halnya dengan tempat penyewaan lapangan futsal pada umumnya di Cianjur. Rajawali Futsal didirikan dengan maksud dan tujuan yaitu sebagai tempat membantu seseorang atau grup ( club) menyalurkan hobi khususnya permainan futsal. Di setiap tempat futsal, terdapat proses Booking yang bertujuan untuk menentukan jadwal pelanggan untuk bermain. Pada saat ini, proses Booking masih dilakukan secara manual artinya calon pelanggan akan datang langsung ke lapang futsal untuk melakukan proses Booking dan pengelola akan mencatat Bookingan tersebut ke dalam jadwal. Kelemahan dalam proses Booking tersebut, pengelola mengalami kesulitan karena banyaknya pelanggan yang akan melakukan Booking, terlebih apabila pelanggan yang sudah melakukan
Booking membatalkan Bookingan secara sepihak. Selain itu, pelanggan pun merasa kesulitan pada saat akan melakukan Booking karena pelanggan diharuskan datang ke lapang secara langsung mengetahui jadwal mana yang bisa dilakukan proses Booking.

Android WebView adalah komponen sistem untuk sistem operasi (OS), Android yang memungkinkan aplikasi Android untuk menampilkan konten dari web langsung kedalam suatu aplikasi. Ada dua cara untuk melihat konten web pada perangkat Android: melalui browser web bawaan atau melalui aplikasi Android yang menyertakan WebView di dalam tata letak.

Jika pengembang ingin menambahkan fungsionalitas browser ke dalam aplikasi, ia dapat menyertakan pustaka WebView dan membuat turunan dari kelas WebView untuk melakukan sesuatu seperti merender halaman web dan menjalankan JavaScript.

Berdasarkan permasalahan yang ada maka rumusan masalah dari penelitian ini adalah bagaimana merancang sebuah aplikasi dengan teknologi Android WebView yang 

Menggunakan Teknologi Android Webview

dapat digunakan oleh server (pengelola) dan client (pelanggan) untuk dapat melakukan proses Booking secara online melihat jadwal Booking futsal, serta memberikan informasi kepada server (pengelola) mengenai pelanggan yang membatalkan Bookingan dan laporan Booking lapangan futsal.

Maksud dari penelitian ini adalah untuk merancang aplikasi penjadwalan dan Booking online di Rajawali Futsal Cianjur.

Adapun tujuan dalam penelitian yang dilakukan adalah sebagai berikut :

1. Mengimplementasikan aplikasi tersebut dengan menggunakan Android System WebView.

2. Memudahkan Server (pengelola) dan Client (pelanggan) untuk melakukan proses booking secara online

3. Memudahkan server (pengelola) dan client (pelanggan) untuk melihat kosong tidaknya jadwal pada saat Booking futsal.

4. Memberikan informasi kepada server (pengelola) mengenai laporan booking

\section{Landasan Teori}

\subsection{Apliaksi}

Sutabri (2012:147), mengungkapkan "Aplikasi adalah terapan yang difungsikan secara khusus dan terpadu sesuai kemampuan yang dimilikinya".

Supriyanto (2005:2), mengungkapkan "Aplikasi adalah program yang memiliki aktifitas pemroresan perintah yang diperlukan untuk melaksanakan permintaan pengguna dengan tujuan tertentu".

Dari dua pendapat yang telah dikemukanan dapat disimpulkan bahwa aplikasi adalah suatu program atau alat terapan yang dirancang untuk membantu berbagai kegiatan yang dilakukan oleh penggunanya.

\subsection{Penjadwalan}

Penjadwalan adalah aktivitas perencanaan untuk menentukan kapan dan dimana setiap operasi sebagai bagian dari pekerjaan secara keseluruhan harus dilakukan pada sumber daya yang terbatas, serta pengalokasian sumber daya pada suatu waktu tertentu dengan memperhatikan kapasitas sumber daya yang ada. Penjadwalan dapat diartikan sebagai pengalokasian sejumlah sumber daya (resource) untuk melakukan sejumlah tugas atau operasi dalam jangka waktu tertentu dan merupakan proses pengambilan keputusan yang peranannya sangat penting dalam industri manufaktur dan jasa yaitu mengalokasikan sumbersumber daya yang ada agar tujuan dan sasaran perusahaan lebih optimal (Baker \& Trietsch, 2009:25).

Menurut Pinedo (2012:12), penjadwalan dapat didefinisikan sebagai proses pengalokasian sumber daya untuk mengerjakan sekumpulan tugas dalam jangka waktu tertentu dengan 2 arti penting sebagai berikut :

a. Penjadwalan merupakan suatu fungsi pengambilan

keputusan untuk membuat atau menentukan jadwal.

b. Penjadwalan merupakan suatu teori yang berisi

sekumpulan prinsip dasar, model, teknik, dan

kesimpulan logis dalam proses pengambilan keputusan yang memberikan pengertian dalam fungsi penjadwalan.

Penjadwalan dibutuhkan untuk mengurangi alokasi tenaga operator, mesin dan peralatan produksi, dan dari aspek lainnya untuk lebih efisien. Hal ini sangat penting dalam pengambilan keputusan dalam proses kelangsungan produksi.

\subsection{Booking}

Booking (Pemesanan) berasal dari bahasa Inggris yaitu to reserve yang dapat di artikan proses perjanjian berupa pemesanan produk barang ataupun jasa namun belum ditutup oleh suatu pembelian. Dalam kamus besar Bahasa Indonesia reservasi atau pemesanan adalah proses, pembuatan, cara memesan (tempat, barang dan sebagainya) kepada orang lain.

Menurut Edwin dan Chris (1999:1) pemesanan dalam arti umum adalah perjanjian pemesanan tempat antara dua pihak atau lebih, perjanjisan pemesanan tempat tersebut dapat berupa perjanjian atas pemesanan suatu ruangan, kamar, tempat duduk dan lainnya, pada waktu tertentu dan disertai produk jasanya.

\subsection{Online}

Menurut Ashadi Siregar dalam webnya (www.maxmanroe.com:2016) menulis pengertian media online adalah penyebutan umum kepada media berbasis telekomunikasi dan multimedia (komputer dan internet). Media online ini termasuk website, radio-online, pers online, dan e-commerce.

Menurut Lorie Ackerman dalam webnya (www.maxmanroe.com:2016) menulis pengertian media online adalah bentuk penerbitan online yang digunakan untuk menyampaikan berbagai ide. Secara umum, media online menggunakan komputer dalam penulisan, pengeditan, pencetakan, atau proses pengiriman publikasi.

\subsection{Metode Rekayasa Perangkat Lunak}

Metode rekayasa perangkat lunak yang digunakan untuk membuat apliaksi penjadwalan dan booking online dengan Teknologi Android Webview yaitu menggunakan metode Waterfall. Menurut Pressman metode waterfall adalah model klasik yang bersifat sistematis, berurutan dalam membangun software.

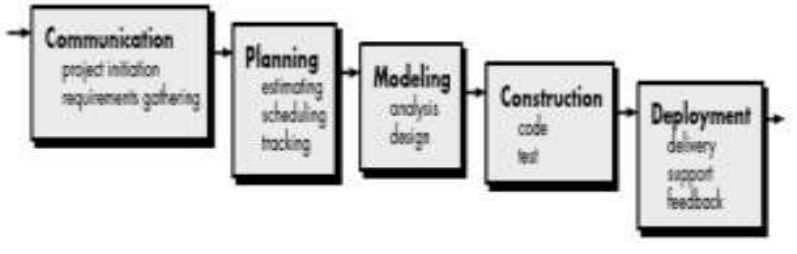

Gambar 1. Model Waterfall (Presman)

\section{Analisis dan Perancangan}

\subsection{Use Case Diagram}

Use case diagram meggunakan tiga aspek system yaitu actor, use case, dan lingkup system. Terdapat delapan (8) function dan dua (2) aktor dalm use case diagram aplikasi penjadwalan dan booking online ini, dimana setiap function yang ada dalam use case diagram tersebut mempunyai fungsi yang berbeda. 


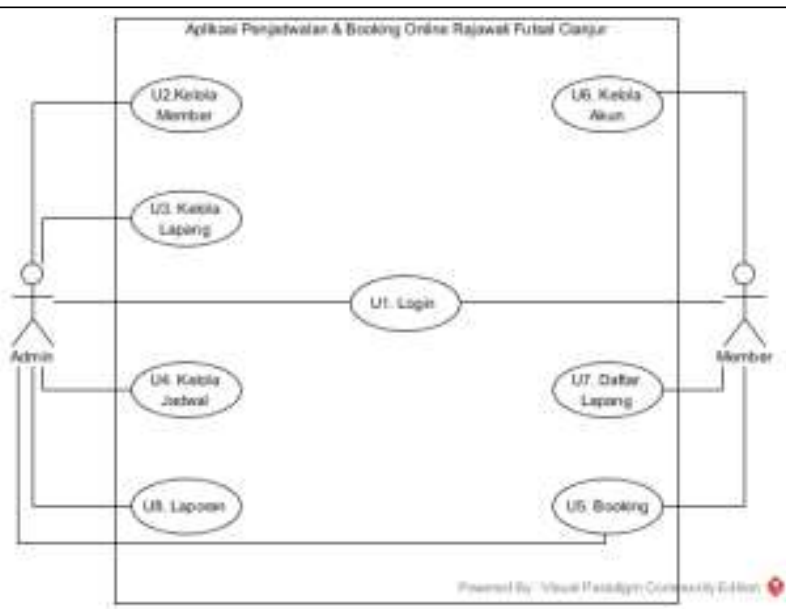

Gambar 2. Use Case Diagram Aplikasi Penjadwalan dan Booking Online

\subsection{Activity Diagram}

Diagram aktivitas atau Activity Diagram menggambarkan workflow (aliran kerja) atau aktivitas dari sebuah sistem atau proses bisnis.

Berikut gambar perancangan dari masing masing aktivitas :

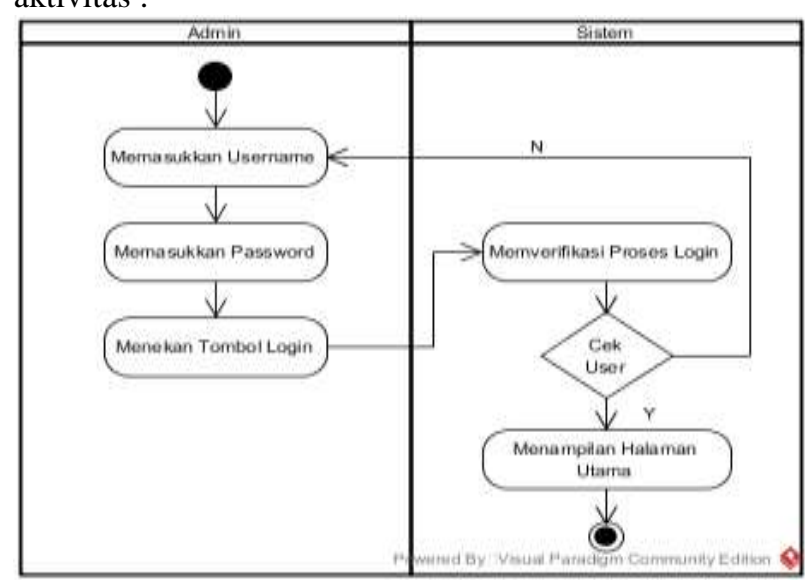

Gambar 3. Activity Diagram Login

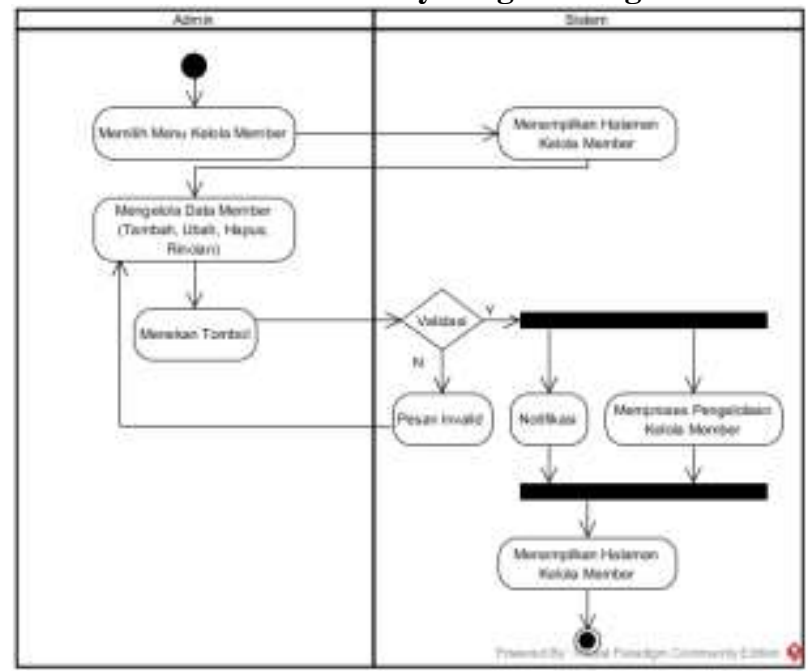

Gambar 4. Activity Diagram Kelola Member

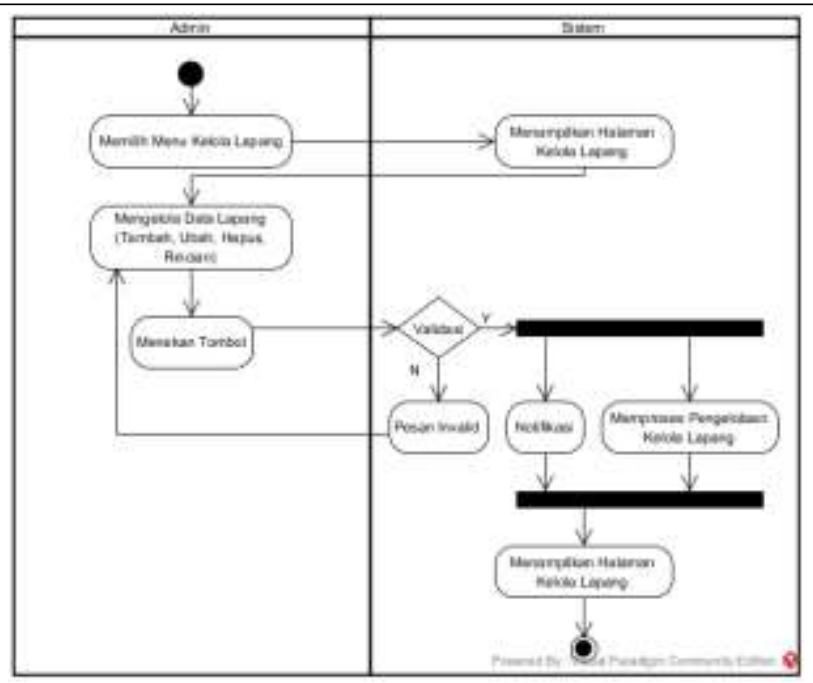

Gambar 5. Activity Kelola Lapang

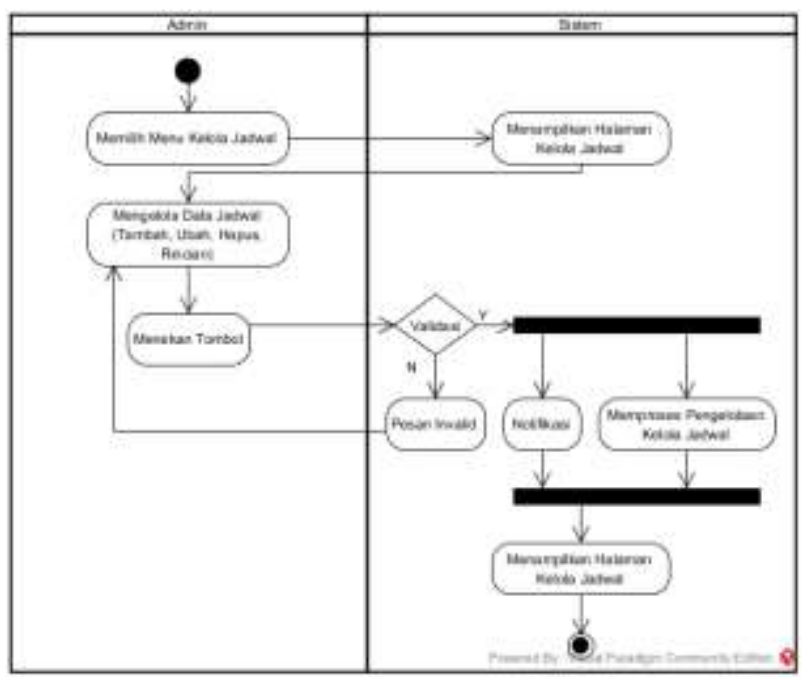

Gambar 6. Activity Kelola Jadwal

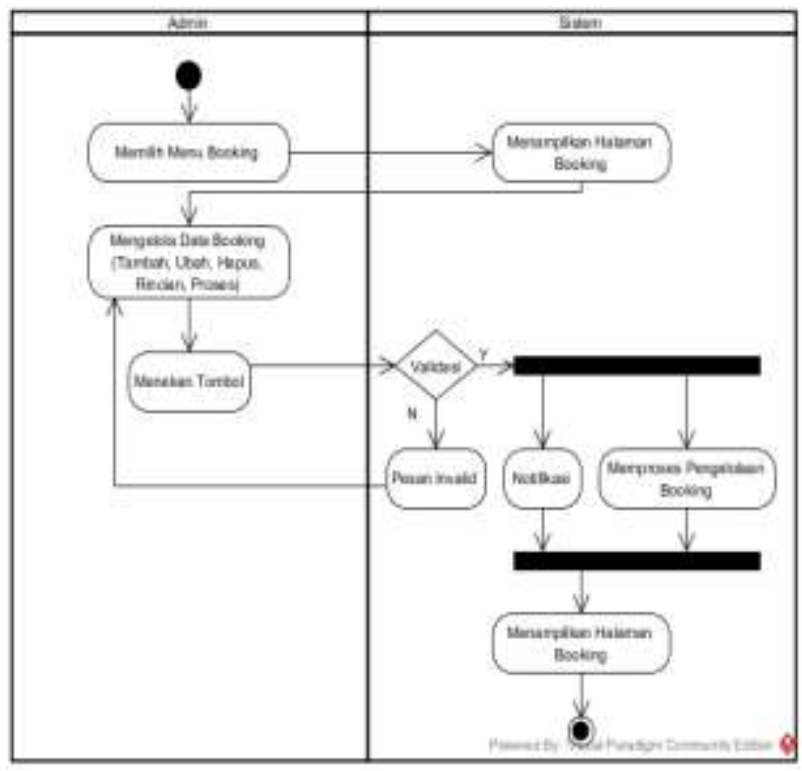

Gambar 7. Activity Diagram Booking 
Fietri Setiawati Sulaeman ${ }^{1}$ M. Firaz Fakhriza Nurjaman², Aplikasi Penjadwalan Dan Booking Online

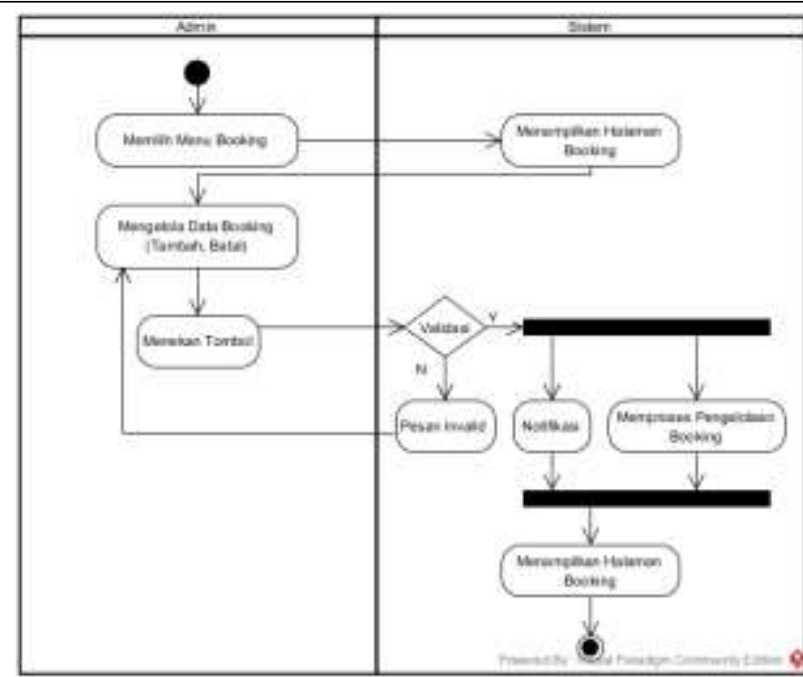

Gambar 8. Activity Diagram Booking Member

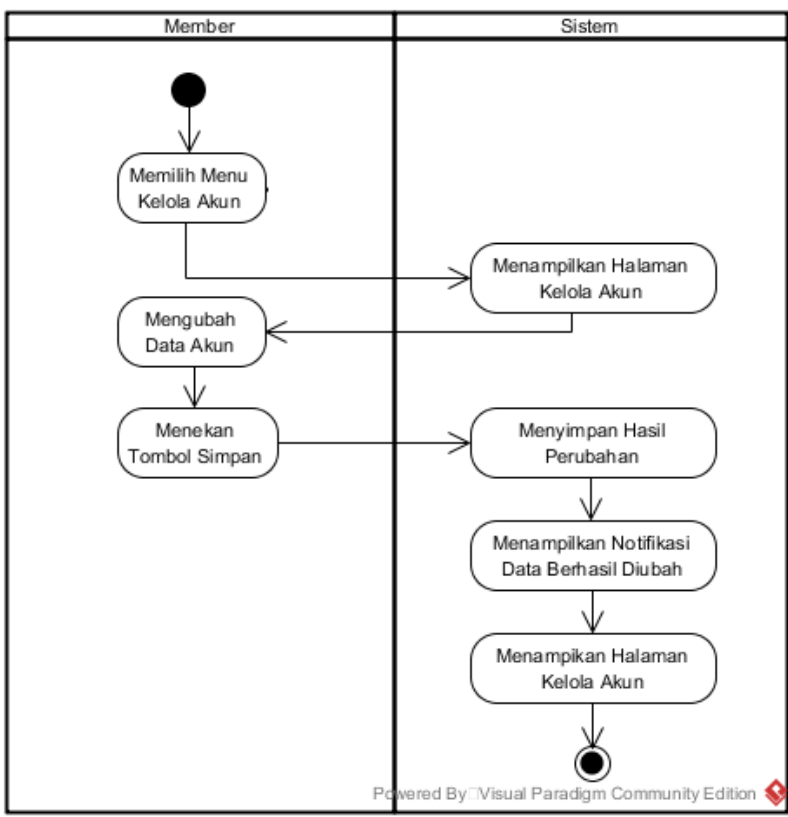

Gambar 9. Activity Diagram Kelola Akun

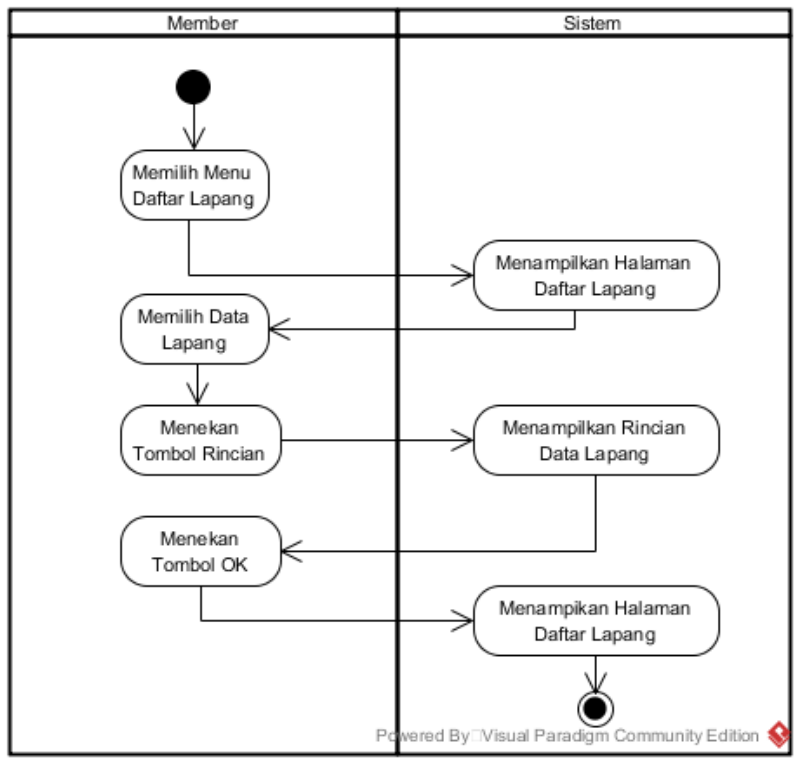

Gambar 10. Activity Diagram Daftar Lapang Menggunakan Teknologi Android Webview

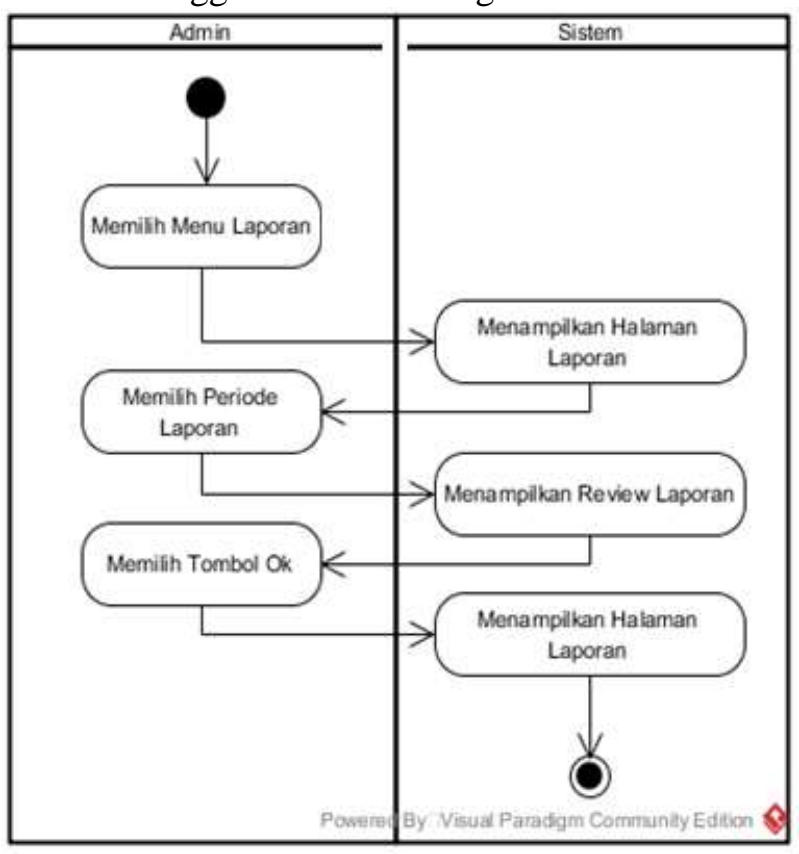

Gambar 11. Activity Diagram Laporan

\subsection{Class Diagram}

Gambar 3.12 merupakan class diagram dari Aplikasi Penjadwalan dan Booking Online di Rajawali Futsal Cianjur

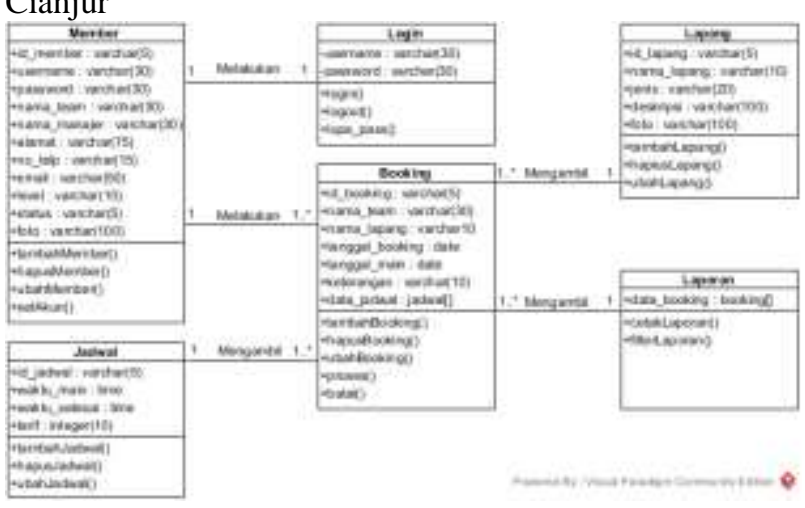

Gambar 12. Class Diagram

\subsection{ERD (Entity Realtionship Diagram)}

Gambar 13. merupakan Entity Relationship Diagram dari Aplikasi Penjadwalan dan Booking Online di Rajawali Futsal Cianjur, terdapat 4 buah entitas yang setiap entitasnya saling berelasi dengan kardinalitas one to many.

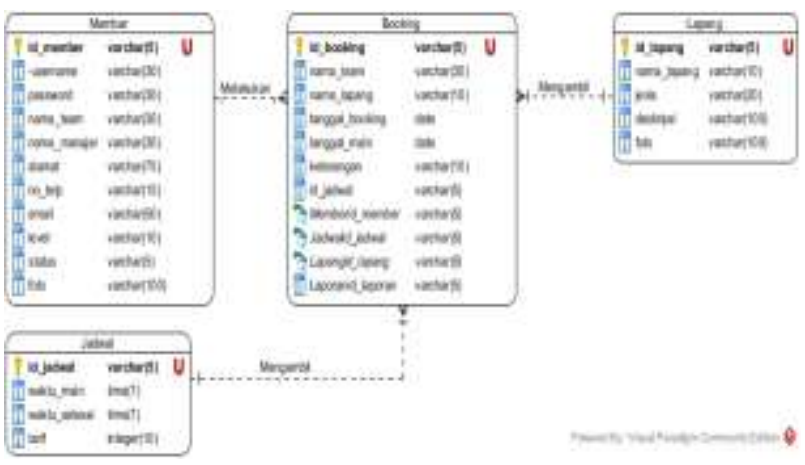

Gambar 13. ERD (Entity Realtionship Diagram) 


\section{Implementasi}

Implementasi ini akan membahas mengenai kebutuhan-kebutuhan perangkat keras, perangkat lunak, implementasi antarmuka, serta source code program.

\subsection{Kebutuhan Perangkat Keras}

Spesifikasi minimun perangkat keras untuk menjalankan Aplikasi Penjadwalan dan Booking Online terdapat pada Tabel 1 .

Tabel 1. Kebutuhan Spesifikasi Perangkat Keras (Hardware)

\begin{tabular}{|l|l|l|}
\hline No & \multicolumn{1}{|c|}{ Perangkat } & \multicolumn{1}{c|}{ Spesifikasi } \\
\hline 1 & Processor & Snapdragon 450 \\
\hline 2 & Penyimpanan Internal & 4 GB \\
\hline 3 & Memory RAM & $512 \mathrm{MB}$ \\
\hline
\end{tabular}

\subsection{Kebutuhan Perangkat lunak}

Spesifikasi perangkat lunak yang dibutuhkan untuk mendukung Aplikasi Penjadwalan dan Booking Online yang akan dibangun adalah sebagai berikut:

a. Sistem Operasi Android

b. Versi Android KitKat atau lebih

c. Google PlayStore

\subsection{Tampilan Antar Muka}

Antarmuka merupakan tampilan halaman aplikasi yang sudah dibuat. Berikut ini akan diuraikan mengenai antarmuka Aplikasi Penjadwalan dan Booking Online.

a. Tampilan antarmuka Halaman Login

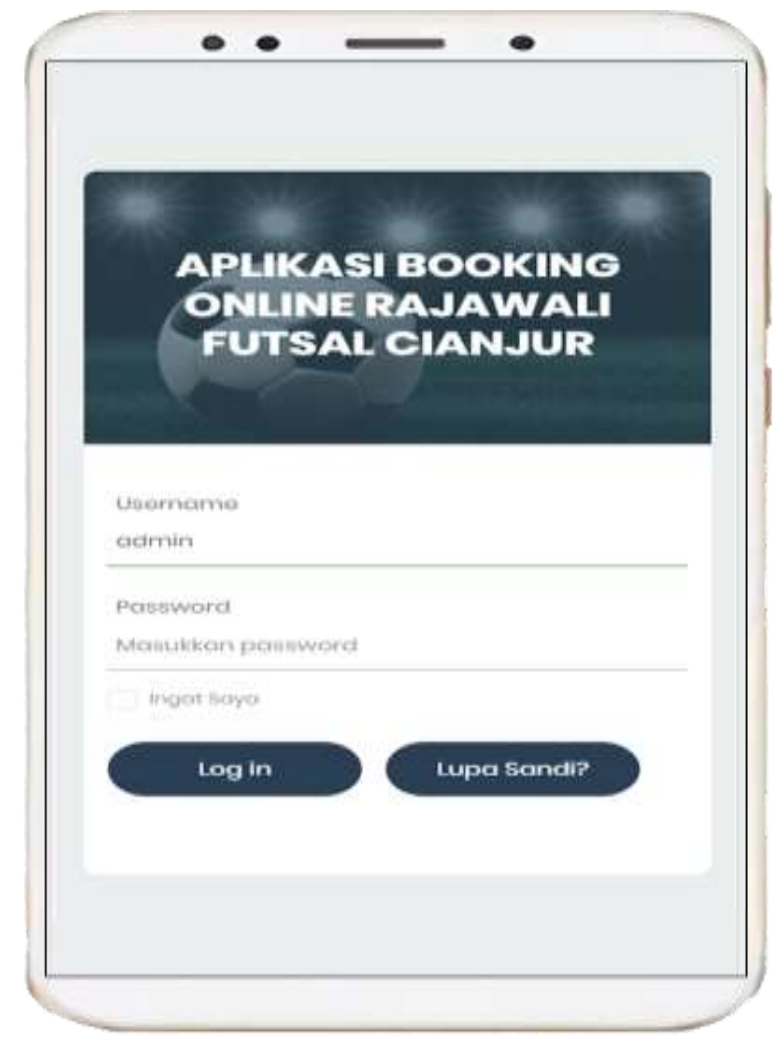

Gambar 14. Antarmuka Halaman Login b. Tampilan antarmuka Halaman Beranda Admin

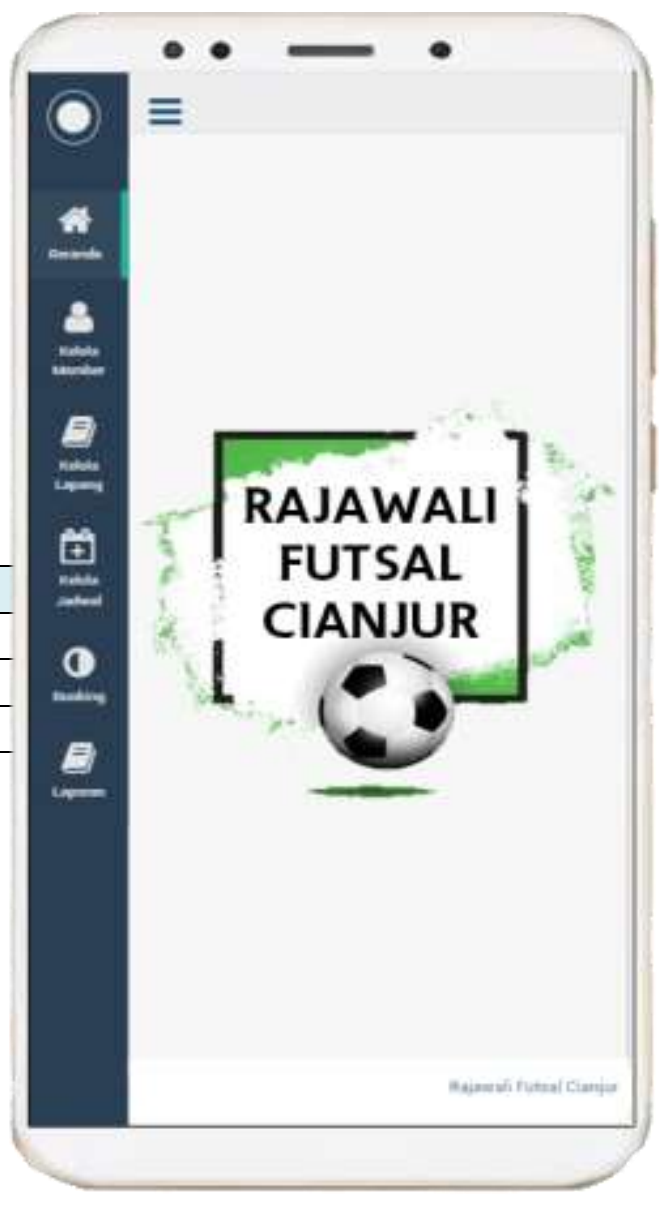

Gambar 15. Tampilan antarmuka Halaman Beranda Admin

c. Tampilan antarmuka Halaman Beranda Member

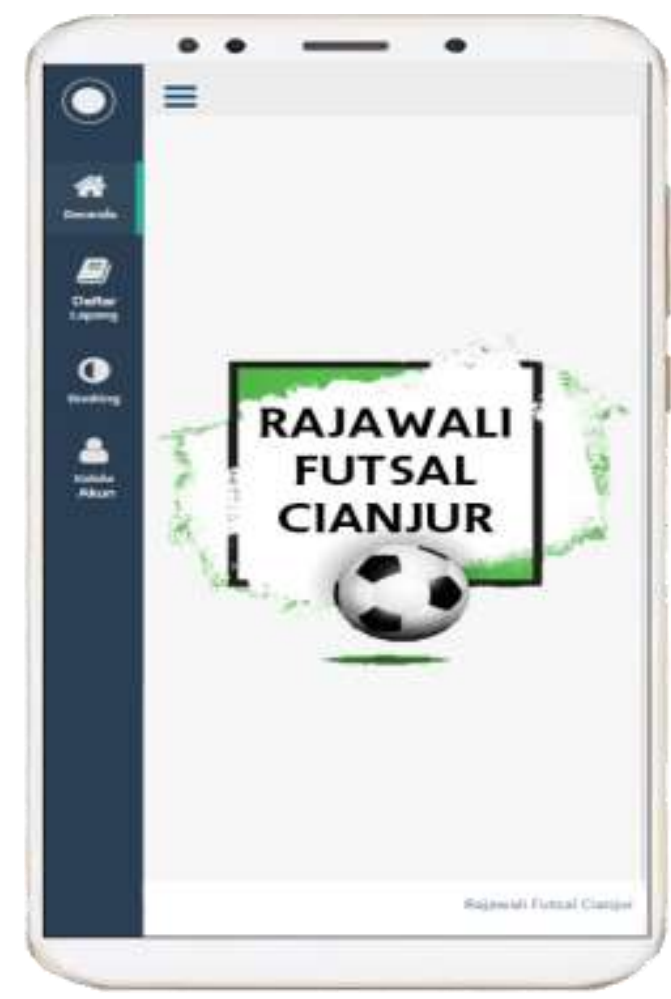

Gambar 16. Tampilan antarmuka Halaman Beranda Member 
Fietri Setiawati Sulaeman ${ }^{1}$ M. Firaz Fakhriza Nurjaman², Aplikasi Penjadwalan Dan Booking Online Menggunakan Teknologi_Android Webview

d. Tampilan antarmuka Halaman Kelola Member

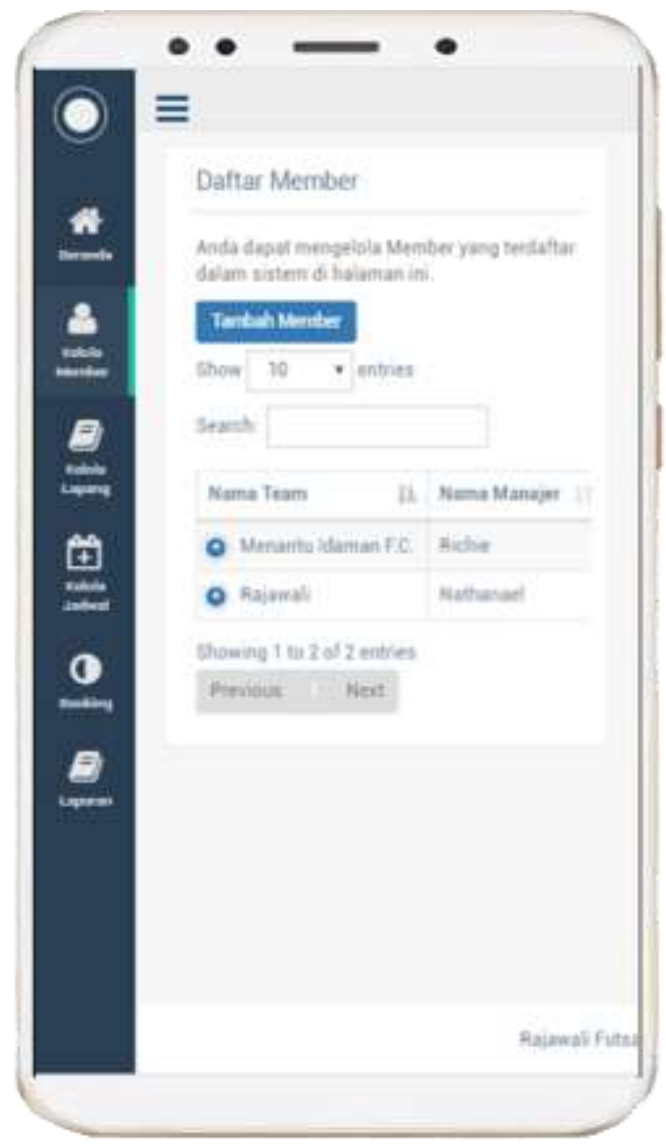

Gambar 17. Tampilan antarmuka Halaman Kelola Member

e. Tampilan antarmuka Halaman Kelola Lapang

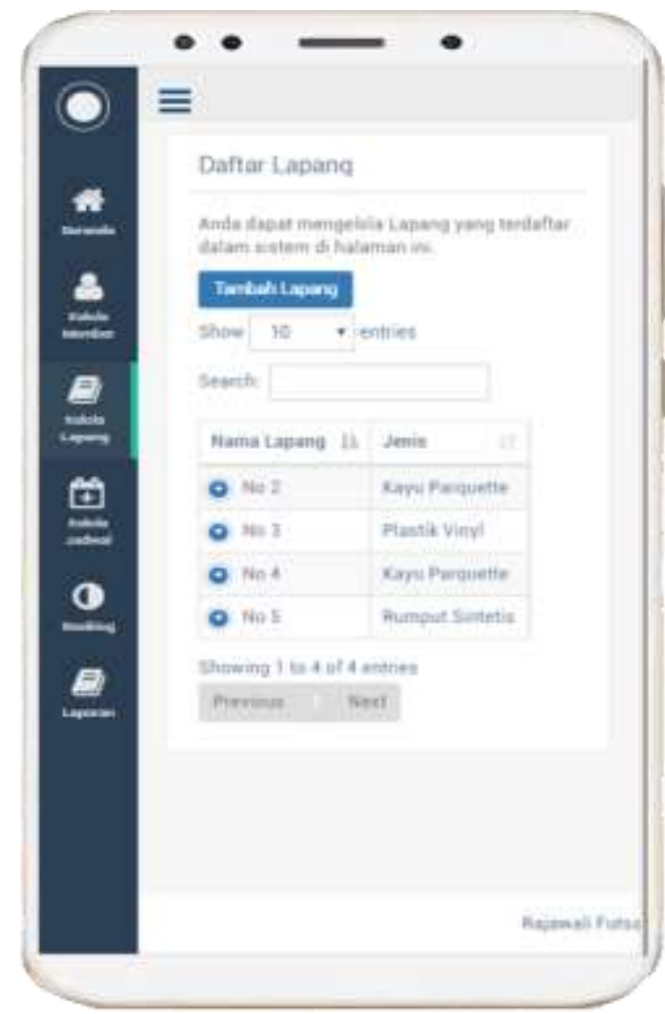

Gambar 18. Tampilan antarmuka Halaman Kelola Lapang f. Tampilan antarmuka Halaman Kelola Jadwal

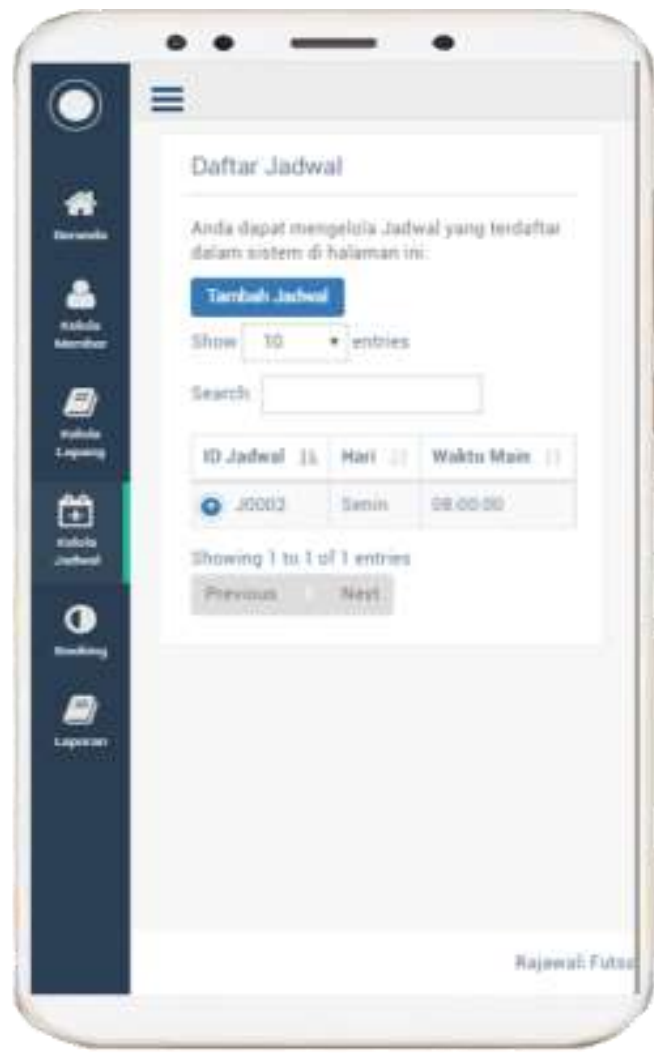

Gambar 19. Tampilan antarmuka Halaman Kelola

\section{Jadwal}

g. Tampilan antarmuka Booking

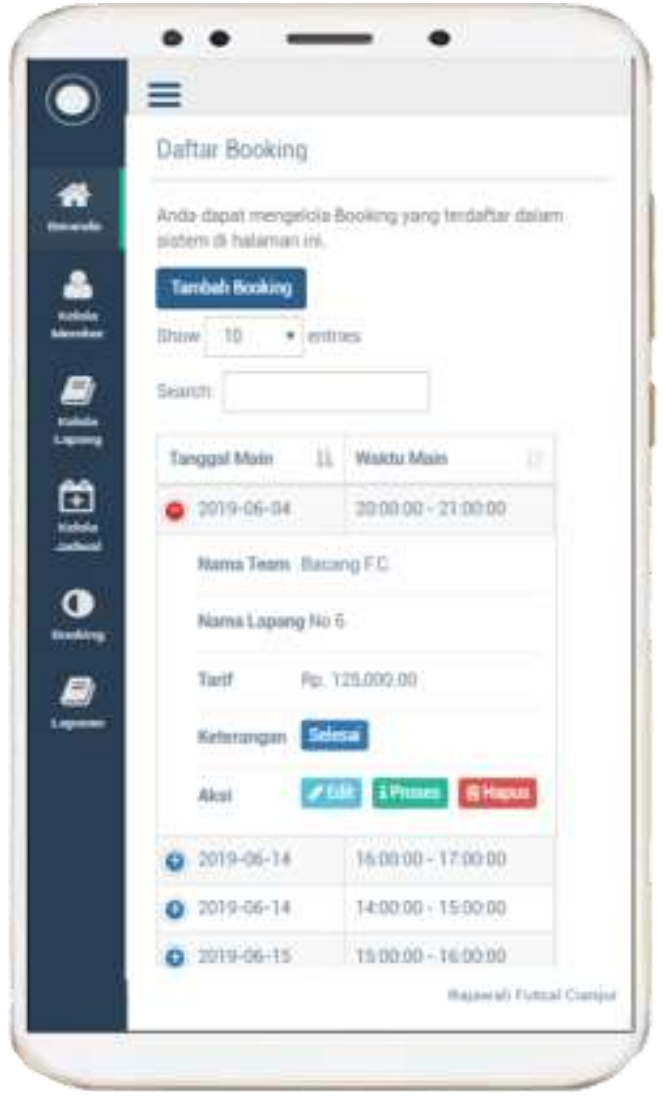

Gambar 20. Tampilan antarmuka Booking 
h. Tampilan antarmuka Laporan

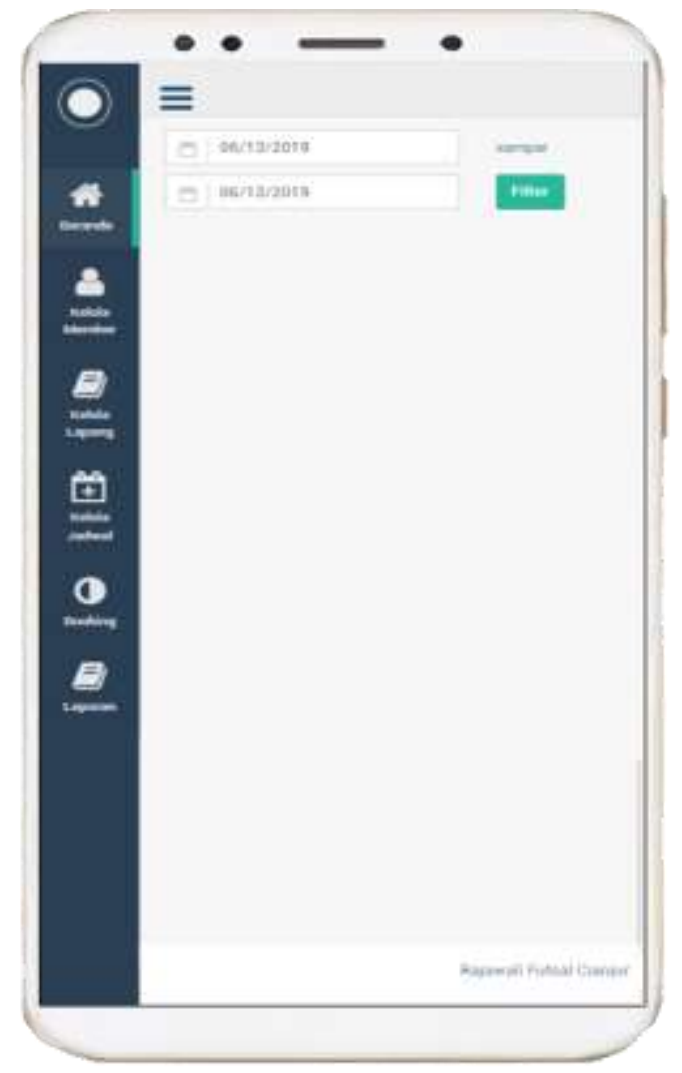

Gambar 21. Tampilan antarmuka Laporan

\section{Simpulan dan Saran}

Dari hasil Penelitian, perancangan, dan Implementasi yang telah dilakukan dari aplikasi Penjadwalan dan Booking Online dengan Teknologi Anroid Webview, dapat simpulkan beberapa simpulan, yaitu :

1. Aplikasi ini dapat memudahkan dalam proses pendaftaran member, pengelolaan lapang, serta penjadwalan dengan lebih rapi, efektif dan efisien.

2. Aplikasi ini dapat membantu dalam proses booking online yang digunakan dengan lebih terorganisir.

3. Aplikasi ini dapat membantu dalam membuat laporan secara cepat.

Berdasarkan hasil analisis yang dilakukan maka penulis mengajukan beberapa saran kepada pihak yang akan mengembangkan sebagai pengembang selanjutnya antara lain:

1. Aplikasi Penjadwalan dan Booking Online ini dikembangkan sesuai dengan kebutuhan fungsional.

2. Aplikasi Penjadwalan dan Booking Online ini dikembangkan dengan menambahkan sistem booking online sehingga member dapat melakukan booking secara online.

\section{Daftar pustaka}

[1] Tata Sutabri. 2012.Analisis Sistem Informasi.Andi. Yogyakarta

[2] Supriyanto. 2005. Perancangan Aplikasi. Surabaya : Widyastana.
[3] Baker, K.R. \& Trietsch, D., 2009. Principles Of Sequencing And Scheduling. New Jersey: John Wiley \& Sons.

[4] Pinedo, Michael L., 2012. Scheduling Theory, Algorithms, and Systems. New York: Springers.

[5] Edwin \& Chris. (1999:1). Pemesanan dalam arti umum.

[6] Ashadi Siregar dalam webnya (www.maxmanroe.com:2016)

[7] Lorie Ackerman dalam webnya (www.maxmanroe.com:2016)

[8] Pressman, Roger S. 2010. Rekayasa Perangkat Lunak : Pendekatan Praktisi. (Buku Satu). Yogyakarta : Andi Offset. 